\title{
BEHAVIOR OF CHICKS SUBJECTED TO THERMAL CHALLENGE
}

\section{PATRICIA F. P. FERRAZ ${ }^{1}$, TADAYUKI YANAGI JUNIOR ${ }^{2}$, TALITA A. C. ALVARENGA ${ }^{3}$, GREGORY M. REIS ${ }^{4}$, ALESSANDRO T. CAMPOS ${ }^{5}$}

\begin{abstract}
In the first week of a chick life, broilers are very sensitive to different conditions outside their thermoneutral zone. Thus, the goal of this study was to evaluate the behaviors and productive responses of broilers subjected to conditions of thermal comfort or challenge at different intensities (27, 30, 33 and $\left.36^{\circ} \mathrm{C}\right)$ and durations $(1,2,3$ and 4 days starting on the second day of life). In the experiment, ten minutes of images from each hour of each treatment were analyzed to evaluate the key behaviors of the birds. Similar behavior at different dry-bulb air temperatures were identified by using Ward's method of cluster analysis. These behaviors were grouped by dendograms in which the similarity of these data was qualified. Feed intake, water intake and body mass of these animals were evaluated and used to support the observed behaviors. Thus, a similar huddling behavior was observed in the birds from the $2^{\text {nd }}$ to the $5^{\text {th }}$ day of life subjected to $27^{\circ} \mathrm{C}$ and $30^{\circ} \mathrm{C}$, while at $30^{\circ} \mathrm{C}$ and $33^{\circ} \mathrm{C}$ the behavior of accessing feeders and drinkers was also similar. Chicks subjected to $33^{\circ} \mathrm{C}$ presented the best performance, and at 30 and $36^{\circ} \mathrm{C}$ showed intermediate development.
\end{abstract}

KEYWORDS: Grouping of data, Dendogram, Broiler, Productive responses.

\section{COMPORTAMENTO DE PINTINHOS SUBMETIDOS A ESTRESSE TÉRMICO}

RESUMO: Na primeira semana de vida, frangos de corte são muito sensíveis a condições diferentes de suas temperaturas de conforto. Dessa forma, objetiva-se com o presente trabalho avaliar o comportamento e as respostas produtivas de frangos de corte submetidos a condições de conforto e estresse térmico em diferentes intensidades $\left(27 ; 30 ; 33\right.$ e $\left.36^{\circ} \mathrm{C}\right)$ e períodos de duração (1; 2; 3 e 4 dias a partir do $2^{\circ}$ dia de vida). No experimento, diariamente, monitoraram-se dez minutos de imagens de cada hora, de cada tratamento, para a avaliação dos principais comportamentos das aves. Os comportamentos similares em diferentes temperaturas foram identificados usando o método de análise de cluster de Ward e foram agrupados por dendogramas em que se classificou a similaridade destes dados. O consumo de ração, consumo de água e massa corporal destes animais foram avaliados e usados para dar suporte aos comportamentos observados. Dessa forma, observouse o comportamento similar das aves do $2^{\circ}$ ao $5^{\circ}$ dia de vida, submetidas a 27 e $30{ }^{\circ} \mathrm{C}$ em permanecerem agrupadas e/ou isoladas, e a 30 e $33{ }^{\circ} \mathrm{C}$ em permanecerem nos bebedouros e/ou comedouros. As aves submetidas a $33^{\circ} \mathrm{C}$ apresentaram o melhor desempenho, e a 30 e $36^{\circ} \mathrm{C}$ apresentaram desempenhos intermediários.

PALAVRAS-CHAVE: Agrupamento de dados. Dendograma. Frango de corte. Respostas produtivas.

\footnotetext{
${ }^{1}$ Zootecnista, Profa. Doutora, Departamento de Engenharia, UFLA/Lavras - MG, Fone: (35)38291681, patricia.ponciano@deg.ufla.br

${ }^{2}$ Eng $^{\circ}$ Agrícola, Prof. Doutor, Departamento de Engenharia, UFLA/Lavras - MG, Fone: (35)3829-1374, yanagi@deg.ufla.br

${ }^{3}$ Graduanda em Zootecnia, Departamento de Zootecnia, UFLA/Lavras - MG, talitacalvarenga@zootecnia.ufla.br

${ }^{4}$ Cientista da Computação, Mestrando em Engenharia de Sistemas, Departamento de Engenharia, UFLA/Lavras -

MG, muradreis@hotmail.com

${ }^{5}$ Eng ${ }^{\circ}$ Agrícola, Prof. Doutor, Departamento de Engenharia, UFLA/Lavras - MG, Fone: (35)3829-1486, campos@deg.ufla.br Recebido pelo Conselho Editorial em: 21-6-2013

Aprovado pelo Conselho Editorial em: 10-6-2014
} 


\section{INTRODUCTION}

Air temperature is considered the environmental factor of greater impact on performance of broilers. The heating systems more commonly used in Brazilian facilities usually do not produce constant temperatures and often exceed the required (VIGODERIS et al. 2010), which can cause losses in the development of birds and even lead to death in extreme cases.

According to MENEGALI et al. (2013) the newborn chicks have difficulties in retaining body heat as they act like poikilotherm animals, because their thermoregulatory capacity are not well developed (MUJAHID, 2010). Thus, the young birds need to be inserted in environments with appropriate temperature to keep their body temperature approximately constant (CORDEIRO et al., 2011).

However, only the quantification of the thermal environment into which an animal is submitted is not sufficient to obtain the real needs of the welfare for the animal, and the rearing environment directly influences on its behavioral expression in physiological and productive responses (NAZARENO et al., 2011).

The study of animal behavior takes on an important role within the global poultry production, since it improves ancient housing methods into new management techniques, feeding and facilities. The characterization of the standard and of the structure of animal behavior is an important task to understand the complex interactions between individuals and their environment (CORDEIRO et al., 2011).

In this context, this study was conducted aiming at assessing the behavior and productive responses of broilers subjected to different intensities and durations of thermal stress.

\section{MATERIAL AND METHODS}

\section{Experimental site and animals}

The experiment was carried out in four thermal environment-controlled wind tunnels with air recirculation and partial renewal (Figure 1) located at the Animal Environment Laboratory AELab, in the Department of Engineering, at UFLA, Lavras, Minas Gerais, Brazil. Thus, the 16 treatments (subsequently specified) were assessed in groups of four treatments at a time. The conduction of the experiment in these four different phases was expected not to affect the experimental results because the environmental conditions within the tunnels were fully controlled and the chicks used were homogenous. The homogeneity of the chicks was addressed through their similarity in body mass, origin (from the same hatchery) and sanitary condition (received the same vaccine).

All procedures used in this experiment were approved by the Ethics Committee on Animal Use (Comissão de Ética no Uso de Animais, CEUA) of the Federal University of Lavras (Universidade Federal de Lavras - UFLA, Minas Gerais, Brazil), Protocol No. 001/12.

The control, measurement, and storage of the thermal environment variables in the wind tunnels were performed in one-minute intervals using a control and measurement data logger (CR1000, Campbell Scientific ${ }^{\circledR}$, Logan, Utah, USA) having accuracy within $0.3{ }^{\circ} \mathrm{C}, 0.5 \%$ and 0.1 $\mathrm{m} \mathrm{s}^{-1}$ for the range of the $t_{\mathrm{db}}$, relative humidity $(\mathrm{RH})$ and air velocity $(\mathrm{V})$, respectively. 


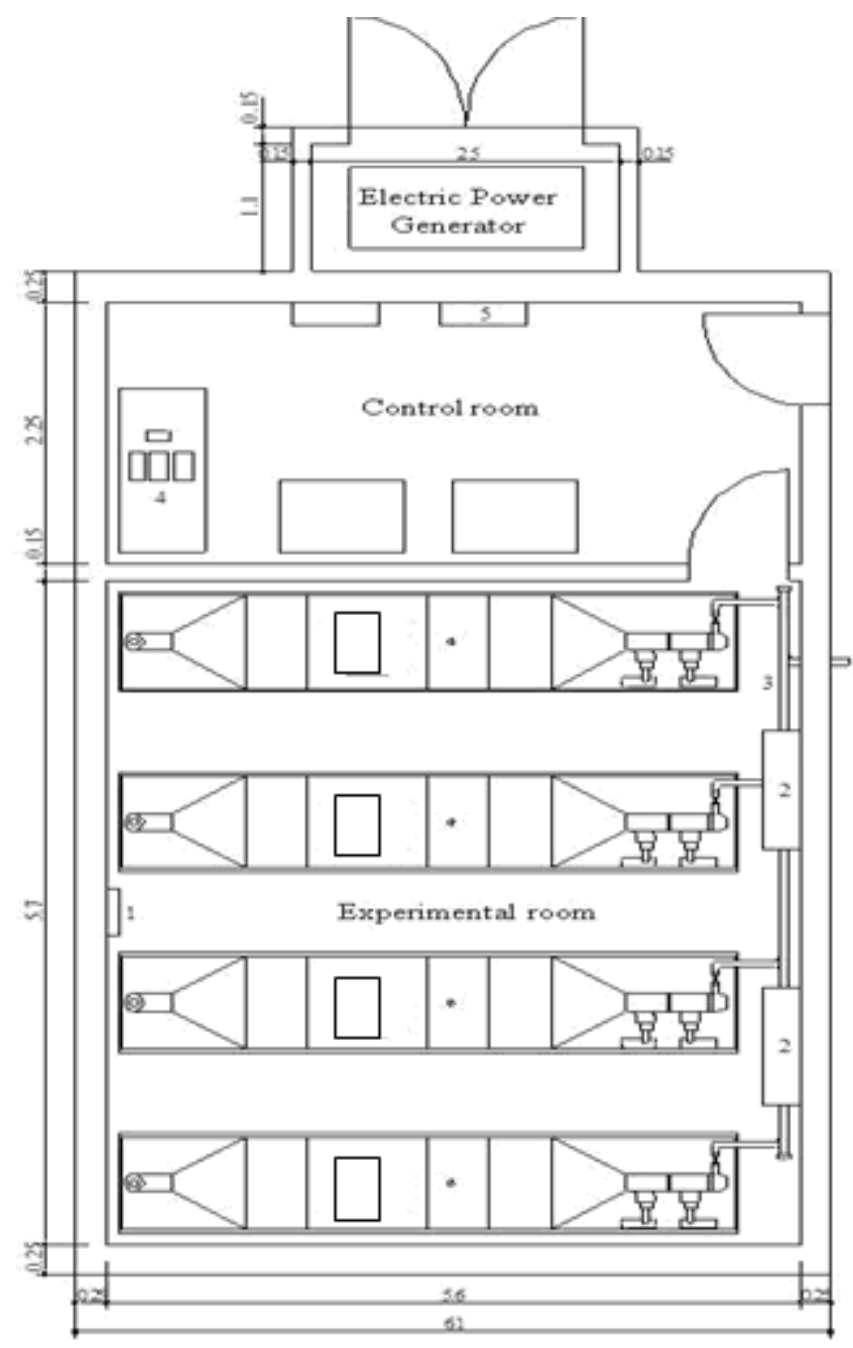

1. Contactors

2. Air conditioner

3. Air outlet ducts

4. Module for data acquisition and storage, and thermal environment

FIGURE 1. Schematic illustration of wind tunnels installed inside a room equipped with cooling system.

Two hundred and ten broilers, males and females, originated from the same hatchery were used during the experimental period. The birds entered the experiment (wind tunnel) on the day of hatch and remained therein until the end of the experimental period. The broilers were housed, within the environmentally-controlled wind tunnels, in cages of $0.40 \times 0.60 \mathrm{~m}$ each, divided into three equal parts at $0.08 \mathrm{~m}^{2}$ each (Figure 2). The cages were oriented in a parallel arrangement to the air flow. Hence, all the chicks were subjected to the same condition of the air. The cages were built with steel bars and wire netting with a mesh of $1 \mathrm{~cm} \mathrm{x} 1 \mathrm{~cm}$. 
a)

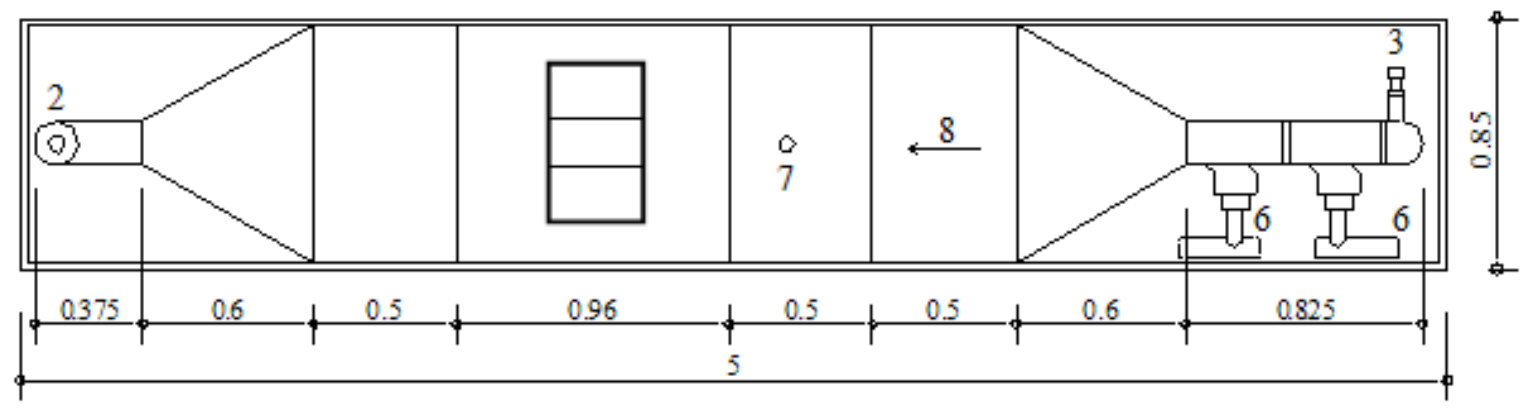

b)

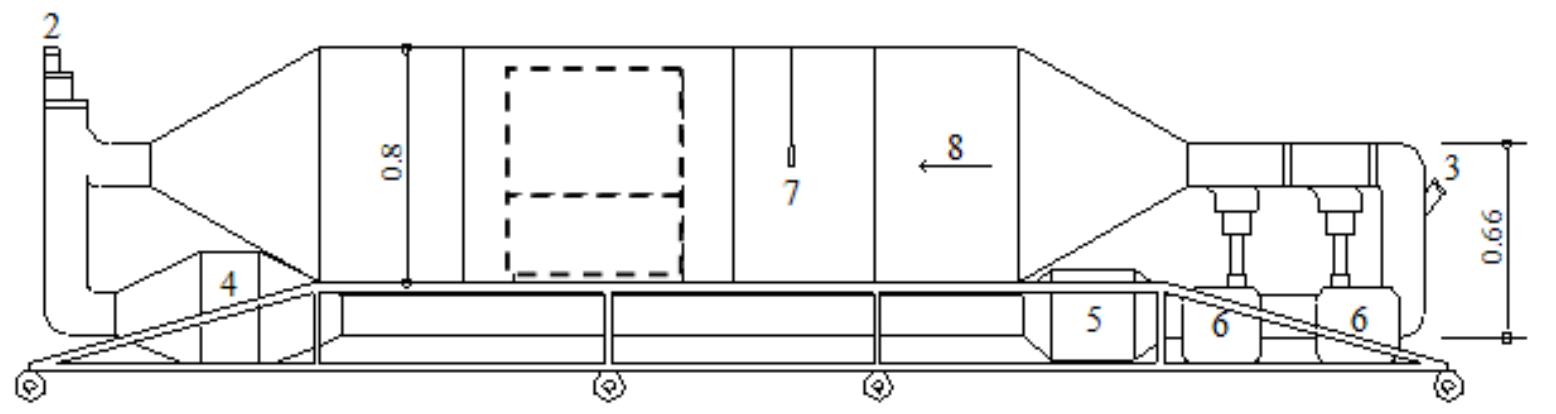

1. Cages for the animals divided in 3 parts parallel to the flow

5. Heater system

2. Air inlet ducts

6. Humidifiers

3. Air outlet ducts

7. Air temperature, humidity and velocity sensors

4. Cooling fan

8. Airflow direction

FIGURE 2. Top (a) and side (b) views of the wind tunnels.

Water and commercial feed for the initial phase were provided to the birds ad libitum during the experiment. Feed with the same formulation was used for all chicks during the entire experimental period, which was composed by $12 \%$ of moisture, $16 \%$ of crude protein, $2 \%$ of ether extract, $10 \%$ of mineral matter, $7 \%$ of fibrous matter, $10-20 \mathrm{~g} / \mathrm{kg}$ of calcium, $5000 \mathrm{mg} / \mathrm{kg}$ of phosphorus, $3900 \mathrm{mg} / \mathrm{Kg}$ of lysine, $1100 \mathrm{mg} / \mathrm{kg}$ of methionine.

Continuous lighting program was adopted during the first 22 days of life (Abreu et al., 2011).

\section{Treatments}

The animals were placed within the wind tunnels on the first day of life, upon arrival from the hatchery, with the air temperature in the wind tunnel at thermoneutral temperature of $33{ }^{\circ} \mathrm{C}$ (Menegali et al., 2013). Each group of 15 birds, housed in the same tunnel, was subjected to 1 of the 16 treatments listed in Table 1 from the second day of life. The air temperature was returned to the thermoneutral temperature recommended for the first week of life $\left(33^{\circ} \mathrm{C}\right)$ once the thermal challenge was over.

Within each wind tunnel, where the cages were housed, the birds were divided into three regions with the same area, setting up a repetition for each treatment. The area of each wind tunnel intended for allocation of the cage had the upper side closed with plastic film, thus allowing the shooting of video images for evaluation of the animal behavior. 
TABLE 1. Evaluated treatments

\begin{tabular}{|c|c|c|c|}
\hline Treatments & $\begin{array}{l}\text { Air dry-bulb temperature } \\
\qquad\left({ }^{\circ} \mathrm{C}\right)\end{array}$ & $\begin{array}{l}\text { Air humidity } \\
\text { (\%) }\end{array}$ & Days in thermal stress \\
\hline 1 & $27 \pm 0.2^{\circ} \mathrm{C}$ & $60 \pm 0.3$ & $2^{\text {nd }}$ day of life \\
\hline 2 & $27 \pm 0.3^{\circ} \mathrm{C}$ & $60 \pm 0.3$ & $2^{\text {nd }}$ and $3^{\text {rd }}$ days of life \\
\hline 3 & $27 \pm 0.2^{\circ} \mathrm{C}$ & $60 \pm 0.6$ & $2^{\text {nd }}, 3^{\text {rd }}$ and $4^{\text {th }}$ days of life \\
\hline 4 & $27 \pm 0.2^{\circ} \mathrm{C}$ & $60 \pm 0.3$ & $2^{\text {nd }}, 3^{\text {rd }}, 4^{\text {th }}$ and $5^{\text {th }}$ days of life \\
\hline 5 & $30 \pm 0.3^{\circ} \mathrm{C}$ & $60 \pm 0.4$ & $2^{\text {nd }}$ day of life \\
\hline 6 & $30 \pm 0.3^{\circ} \mathrm{C}$ & $60 \pm 1.0$ & $2^{\text {nd }}$ and $3^{\text {rd }}$ days of life \\
\hline 7 & $30 \pm 0.3^{\circ} \mathrm{C}$ & $60 \pm 0.7$ & $2^{\text {nd }}, 3^{\text {rd }}$ and $4^{\text {th }}$ days of life \\
\hline 8 & $30 \pm 0.2^{\circ} \mathrm{C}$ & $60 \pm 0.3$ & $2^{\text {nd }}, 3^{\text {rd }}, 4^{\text {th }}$ and $5^{\text {th }}$ days of life \\
\hline 9,10,11,12 (control) & $33^{\circ} \mathrm{C} \pm 0.2^{\circ} \mathrm{C}$ & $60 \pm 0.5$ & No day on week 1 \\
\hline 13 & $36 \pm 0.6^{\circ} \mathrm{C}$ & $60 \pm 0.3$ & $2^{\text {nd }}$ day of life \\
\hline 14 & $36 \pm 0.5^{\circ} \mathrm{C}$ & $60 \pm 1.0$ & $2^{\text {nd }}$ and $3^{\text {rd }}$ days of life \\
\hline 15 & $36 \pm 0.6^{\circ} \mathrm{C}$ & $60 \pm 0.5$ & $2^{\text {nd }}, 3^{\text {rd }}$ and $4^{\text {th }}$ days of life \\
\hline 16 & $36 \pm 0.5^{\circ} \mathrm{C}$ & $60 \pm 0.4$ & $2^{\text {nd }}, 3^{\text {rd }}, 4^{\text {th }}$ and $5^{\text {th }}$ days of life \\
\hline
\end{tabular}

\section{Image acquisition}

To be possible to observe the behaviors of the birds during all evaluated days, a video camera was installed in each of the four acclimatized wind tunnels. All cameras were connected to a microcomputer equipped with software for acquisition and storage of images. The four video cameras were positioned perpendicular to the floors of the cages at $1 \mathrm{~m}$ height, which allowed the obtainment of sharp images of the birds. The cameras, were made by the brand TRENDnet ${ }^{\circledR}$, model TV-IP422W with 1/4" color CMOS sensor, and they had an image resolution of 640x480 pixels.

Images were recorded from the second day (beginning of treatment) until the fifth day of life, totalizing ninety-six hours of video footage, from only one of the replicates of each treatment (five animals). The behavioral images analyzed represented conditions without other interferences such as outside noises and entry of personal. Subsequently, the average daily behavior of each of the sixteen treatments was calculated.

\section{Assessment of behavior}

Ten minutes of video images at the beginning of each hour were analyzed per treatment. For every ten minutes observed, there was a listing of behavioral units (ethogram) of the birds, as well as how many minutes each bird spent on this behavior to observe the condition of comfort or discomfort of the animals subjected to the different thermal regimens.

The main behaviors analyzed were: birds huddling in groups, presence of birds at the drinker, presence of birds at the feeder, birds spread apart in the cage. These behaviors were adapted from SEVEGNANI et al. (2005).

\section{Cluster Analysis}

The behaviors of birds were analyzed using agglomerative hierarchical grouping, or clustering analysis, which is used to separate objects into groups based on characteristics of the objects. The basic idea is to put in the same group objects that are similar according to some predetermined criterion (Linden, 2009). Within each cluster, the objects are similar to each other, while objects located in other clusters are different from one another (DOMINICK et al., 2012).

In cluster analysis, there are two main types of techniques: hierarchical and divisive. The goal of divisive technique is a separate set of consistent objects within groups, while the hierarchical, objects are aggregates progressively until they were united into a single cluster. The technique of hierarchical clustering interconnects samples by their associations, producing a dendrogram where similar samples to the chosen variables are grouped together. The dendograms are especially useful 
in visualizing similarities between samples or objects represented by points in space where the conventional representation of graphs is not possible (LAU et al., 2009).

The classification of objects can be illustrated by dendogram showing similarity levels, quantified by the method agglomerative hierarchical of Ward and the dissimilarity were measured by the Euclidean distance (LAU et al., 2009). The Euclidean distance (DE) [eq. (1)] is based on a single binding (also known as nearest neighbor) referred to as the quotient between the distance of connection or linkage distance $\left(\mathrm{D}_{\text {link }}\right)$ divided by the maximum distance $\left(\mathrm{D}_{\max }\right)$ (DOMINICK et al., 2012). To standardize the bond distance represented by y-axis, the ratio is usually multiplied by 100.

$$
\mathrm{DE}=\left[\left(\frac{\mathrm{Dlink}}{\mathrm{Dmax}} \times 100\right)\right]
$$

The Ward method is described by MELO JÚNIOR et al. (2006) and considered initial cluster, those individuals who provide the lowest sum of squares of deviations.

The grouping is made from the sum of squares of deviations (SQD) or between accesses from the square of the Euclidean distance, since there is the relation expressed by eqs. (2) and (3), respectively.

$$
\begin{aligned}
S Q D_{i i^{*}} & =\frac{1}{2} d_{i i^{*}}^{2} \\
S Q D_{i i^{*}} & =\sum_{j=1}^{n} S Q D_{j\left(i i^{2}\right)}
\end{aligned}
$$

where,

$\mathrm{SQD}_{\mathrm{ii}}$ ' = the sum of squared deviations to the $\mathrm{j}^{\text {th }}$ variable, considering the positions $\mathrm{i}$ and $\mathrm{i}$ ';

$\mathrm{d}_{\mathrm{ii}}^{2}=$ Square of the Euclidean distance between the positions i and i';

$\mathrm{n}=$ number of evaluated variables.

The sum of total squares of deviations (SQDT) is given by [eq. (4)].

$$
\mathrm{SQDT}=\frac{1}{\mathrm{~g}} \sum_{\mathrm{i}<}^{\mathrm{E}} \sum_{\mathrm{i}^{2}}^{\mathrm{E}} \mathrm{d}_{\mathrm{ii}}^{2}
$$

where,

$\mathrm{g}=$ number of air temperatures evaluated to be grouped $\left(27,30,33\right.$ and $\left.36^{\circ} \mathrm{C}\right)$.

The linear correlation coefficient of Pearson between elements of the matrix of dissimilarity (matrix of distances between individuals, obtained from the original data) and the cophenetic matrix elements (matrix of distances between individuals, obtained from the dendogram) is called cophenetic correlation coefficient (r). This coefficient can be used to evaluate the consistency of grouping pattern of hierarchical grouping methods, with values close to unity indicate better representation (CARGNELUTTI FILHO \& GUADAGNIN, 2011).

\section{Productive responses}

In order to subsidize the behavioral results, information on the productive responses was evaluated. The production performance was evaluated daily using the following indexes: feed intake (FI), water intake (WI) and body mass (BM), which was obtained by daily weighing of fifteen animals of each treatment through a digital scale $( \pm 0.001 \mathrm{~kg})$.

Daily, the data for BM, FI and WI was collected from all animals of each treatment, however for purposes of statistical analysis, the average of the plots, i.e. the average of animals in each repetition was used. 


\section{Statics analysis}

To investigate the behavior of birds and group of those according to their similarity data were subjected to multivariate clustering (R CORE TEAM, 2012). The estimate of the correlation adjustment of the cophenetic coefficient between dissimilarity matrix and dendogram was performed in the same software.

The analysis of variance was performed using SAS software (Statistical Analysis System, 2013), with the procedures PROC REG and PROC MIXED, comparing productive responses (FI, WI and BM) among the sixteen treatments. The averages were compared by Tukey test at 5\%.

\section{RESULTS AND DISCUSSION}

To evaluate the behavior of the birds during the experimental period, the method of grouping data in the form of a dendogram (tree) was used. In the dendogram, the level of similarity is indicated on the vertical scale and the air dry-bulb temperatures $\left(\mathrm{t}_{\mathrm{db}}\right)$ are represented on a horizontal axis in a convenient order for grouping. To compare the performance of birds under different $t_{d b}$ and durations of the thermal challenge, an analysis of variance was performed. It was found that for $\mathrm{FI}, \mathrm{WI}$ and BM, the interaction between the sources of variation $\mathrm{rt}_{\mathrm{db}}$ and age was significant (F test, $\mathrm{p}<0.01$ ). However, it is emphasize that the duration of thermal challenge, from 1 to 4 days, did not affect the FI, WI and BM of animals (F test, $\mathrm{p}>0.05$ ). Therefore, only $\mathrm{t}_{\mathrm{db}}$ and bird age were used to analyze these variables.

In the Figure 3 is evident that the time that the birds spent huddling or spread was the same for birds at $27{ }^{\circ} \mathrm{C}$ and $30{ }^{\circ} \mathrm{C}$. The birds spent $68.2 \%$ and $68.8 \%$ of the timewith huddling behavior for $27{ }^{\circ} \mathrm{C}$ and $30{ }^{\circ} \mathrm{C}$, respectively. They spent $11.5 \%$ and $12.26 \%$ of the time in the spread-apart behavior for $27{ }^{\circ} \mathrm{C}$ and $30{ }^{\circ} \mathrm{C}$, , respectively. The birds at $33{ }^{\circ} \mathrm{C}$ showed an intermediate behavior between high and low temperatures (63.3\% of the time they were huddling and $7.0 \%$ spread). Among the four $t_{d b}$ tested, birds at $36{ }^{\circ} \mathrm{C}$ showed the most distinct behavior as observed by the highest distance in the Figure 3. These animals spent $51.4 \%$ of the time huddling and $15.8 \%$ spread. The cophenetic correlation coefficient was 0.96 . This indicates the precision between the original dissimilarity values and those represented in the dendogram of Figure 3.

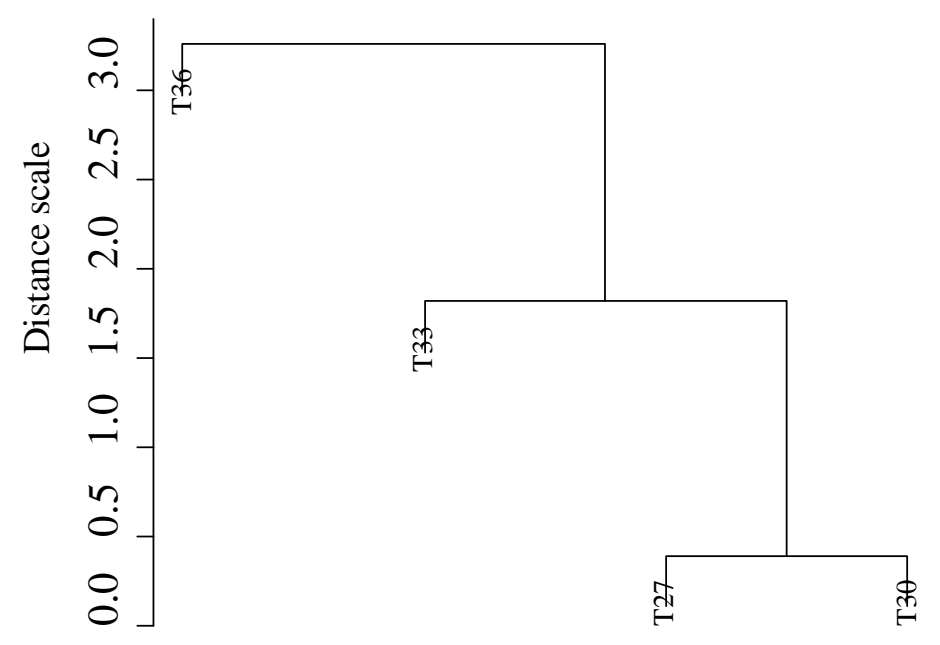

FIGURE 3. Dendogram of behavior: huddled and spread apart for chicks subjected to air temperatures of $27^{\circ} \mathrm{C}, 30^{\circ} \mathrm{C}, 33^{\circ} \mathrm{C}$ and $36^{\circ} \mathrm{C}$.

It is noteworthy, that the most frequent behavior of chicks was to keep huddled, independent of the $t_{d b}$ at which they were exposed. However, it is quite evident that for the birds subjected to lower temperatures $\left(30^{\circ} \mathrm{C}\right.$ and $\left.27{ }^{\circ} \mathrm{C}\right)$ the huddled behavior was more frequent than for the birds at 
higher $t_{d b}\left(36^{\circ} \mathrm{C}\right)$. Thehigher frequency of spread-out behavior were observed in the higher $t_{d b}(36$ ${ }^{\circ} \mathrm{C}$ ). According to CORDEIRO et al. (2011), birds in the first days of life tend to be huddled when subjected to cold stress conditions. This behavior mitigates the loss of sensible heat (radiation, convection and conduction) allowing the birds to better maintain its homeostasis. The bird spreadapart each others under conditions of thermal challenge allows for better ventilation of the body surface, improving the heat loss by radiation and/or convection.

Figure 4 illustrates the behavior of the birds presence in feeders and drinkers. It is observed a similar behavior between the temperatures of $30{ }^{\circ} \mathrm{C}$ and $33^{\circ} \mathrm{C}$. These animals remained in the feeders for $18.0 \%$ and $26.0 \%$ of the time, respectively, and in the drinkers for $3.9 \%$ of the time in both temperatures $\left(30{ }^{\circ} \mathrm{C}\right.$ and $\left.33{ }^{\circ} \mathrm{C}\right)$. The similarity of the results between the behavior of the birds subjected to $30^{\circ} \mathrm{C}$ and $33^{\circ} \mathrm{C}$ agree with the statement made by NIELSEN (2012) that for birds with rapid growth, the optimum temperature may be slightly lower than that recommended, without affecting the animal comfort and productivity.

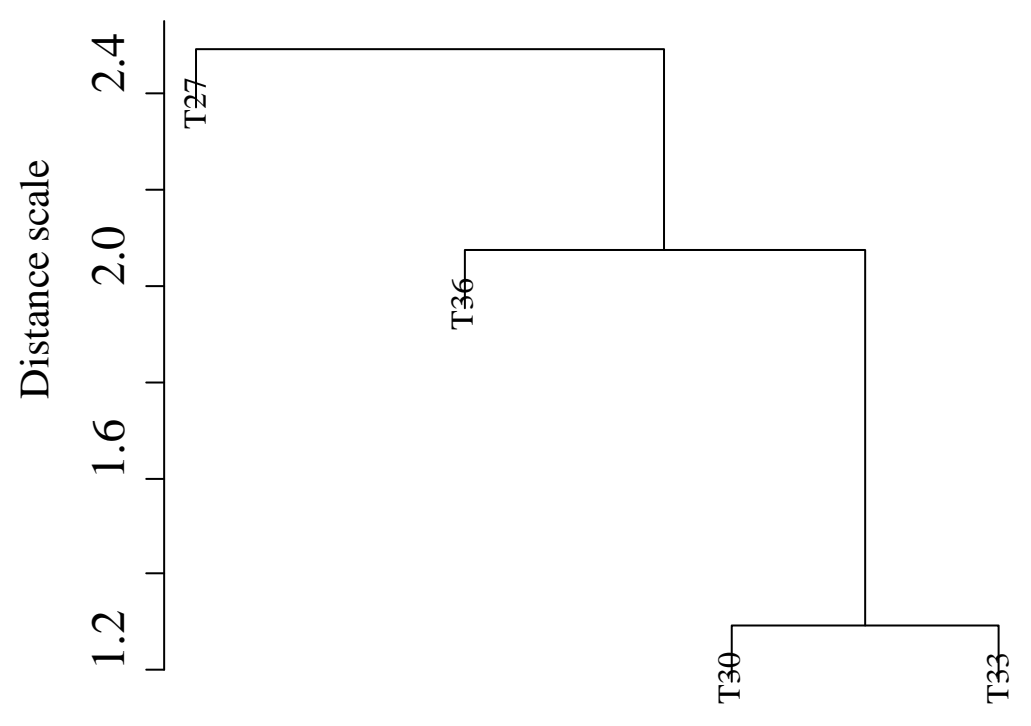

FIGURE 4. Dendogram of behavior: presence in the drinkers and feeder by chicks subjected to temperatures of $27^{\circ} \mathrm{C}, 30^{\circ} \mathrm{C}, 33^{\circ} \mathrm{C}$ and $36^{\circ} \mathrm{C}$.

At $36{ }^{\circ} \mathrm{C}$ the birds behaved differently when compared to other temperatures, wherein they spent $28.1 \%$ of the time at the feeder and $4.8 \%$ of time in the drinker. And at $27{ }^{\circ} \mathrm{C}$, the birds presented an even more different behavior when compared to other $t_{d b}$, spending about $15.3 \%$ of the time at the feeders and $5.0 \%$ of the time in the drinkers. In this case, cophenetic correlation coefficient was 0.77 .

To supplement the behavioral results, data on the productive responses of FI (g), WI (g) and BM (g) were used for the four days of life studied (Figure 5, 6 and 7, respectively). Figure 5 confirms the results shown in Figure 4 wherein behavior of the birds at $30{ }^{\circ} \mathrm{C}$ and $33{ }^{\circ} \mathrm{C}$ was similar in terms of the presence in the feeder and FI. However, it is noteworthy that at $33^{\circ} \mathrm{C}$, the overall FI was higher than in the other three $\mathrm{t}_{\mathrm{db}}$. Furthermore, birds subjected to $27^{\circ} \mathrm{C}$ spent less time at the feeders (Figure 4) and their FI was always lower than at other temperatures. Thermal challenge influences the productivity of livestock by changing its heat exchange with the environment, modifying FI, body mass gain and consequently the metabolism of nutrient (SOUZA et al., 2005; CARVALHO et al., 2011). 


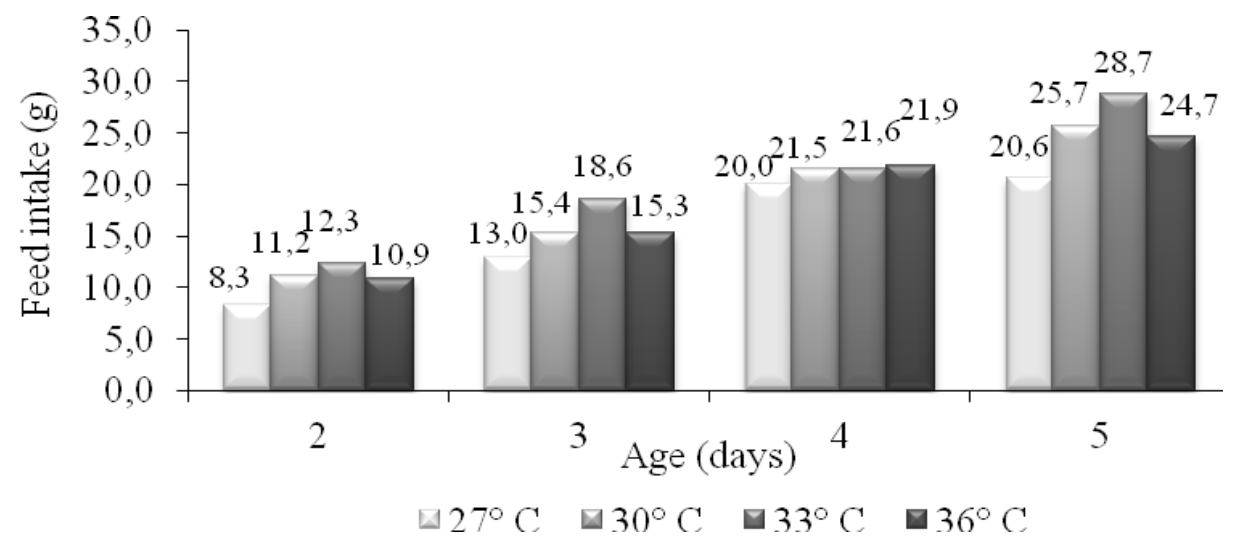

FIGURE 5. Average feed intake (g) of chicks subjected to air dry-bulb temperatures of $27^{\circ}, 30^{\circ}$, $33^{\circ}$ and $36^{\circ} \mathrm{C}$ during the $2^{\text {nd }}, 3^{\text {rd }}, 4^{\text {th }}$ and $5^{\text {th }}$ days of life.

In turn, chicks at $36^{\circ} \mathrm{C}$ had a greater FI when compared to those at $27^{\circ} \mathrm{C}$ and $30^{\circ} \mathrm{C}$. NIELSEN (2012) states that heat dissipation has an important influence on FI (metabolic heat) and growth of fast-growing birds, and generally these birds make the use of behavioral changes to adapt to the heat challenge instead of reducing the FI. This energy intake adjustment seems to be demonstrated in our study.

Although Figure 4 showed that the birds subjected to $27^{\circ} \mathrm{C}$ attended the drinkers more than in other $t_{d b}$, Figure 6 showed that they were not the major consumers of water. As a matter of fact they ingested the least amount of water during the first four days of exposure. It is also observed that WI at $33^{\circ} \mathrm{C}$ and $36^{\circ} \mathrm{C}$ were the highest. LANA et al. (2000) found that the average WI usually corresponds to twice the FI; however this ratio may increase under high temperatures.

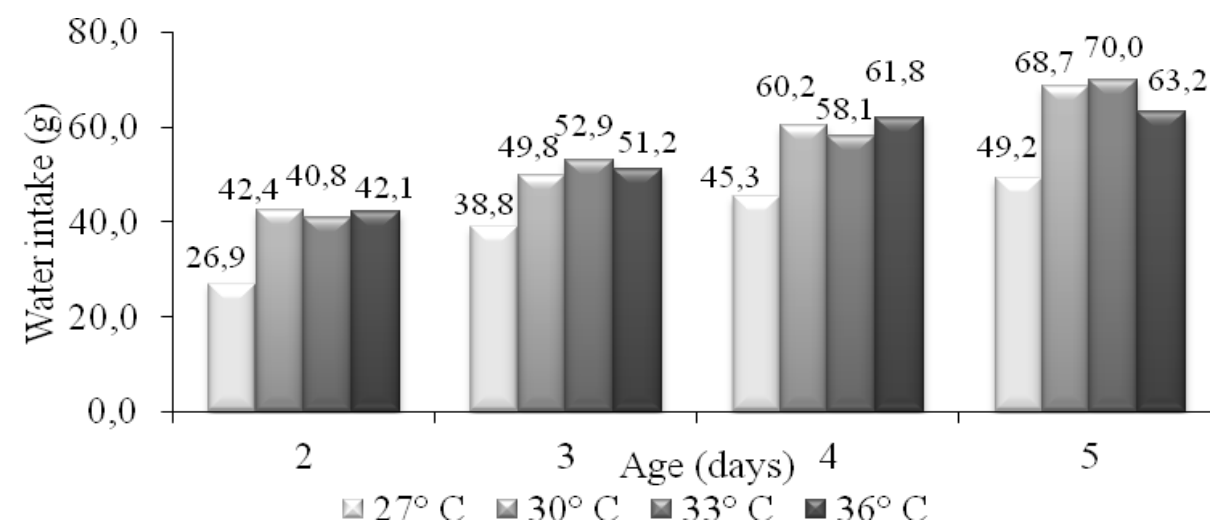

FIGURE 6. Water intake (g) of chicks subjected to air dry-bulb temperatures of $27^{\circ} \mathrm{C}, 30^{\circ} \mathrm{C}, 33^{\circ} \mathrm{C}$ and $36^{\circ} \mathrm{C}$ during the $2^{\text {nd }}, 3^{\text {rd }}, 4^{\text {th }}$ and $5^{\text {th }}$ days of life.

In Figure 7, there is a noticeable difference in $\mathrm{BM}$ between $27^{\circ} \mathrm{C}$ and other $\mathrm{t}_{\mathrm{db}}$. It was concluded that the birds in this situation had smaller amounts of FI (Figure 5) and WI (Figure 6), which resulted in lower values for BM during the study period. KHAN et al. (2011) and KHAN et al. (2012) affirmed that birds have limited physical resources to be spent with growth in response to temperature changes. The adaptation to these challenges requires a redistribution of energy stores and body protein, but it can cause a decrease in growth and weight gain (KHAN et al.; 2011 and KHAN et al.; 2012).

The chicks subjected to $t_{d b}$ at $36^{\circ} \mathrm{C}$ showed $\mathrm{BM}$ larger than those subjected to $t_{d b}$ at $27^{\circ} \mathrm{C}$ and $30^{\circ} \mathrm{C}$. This might be explained by adaptation to thermal conditions to which the birds were exposed. As reported by ABREU et al. (2012), young birds have a higher resistance to heat and greater susceptibility to cold stress conditions. 


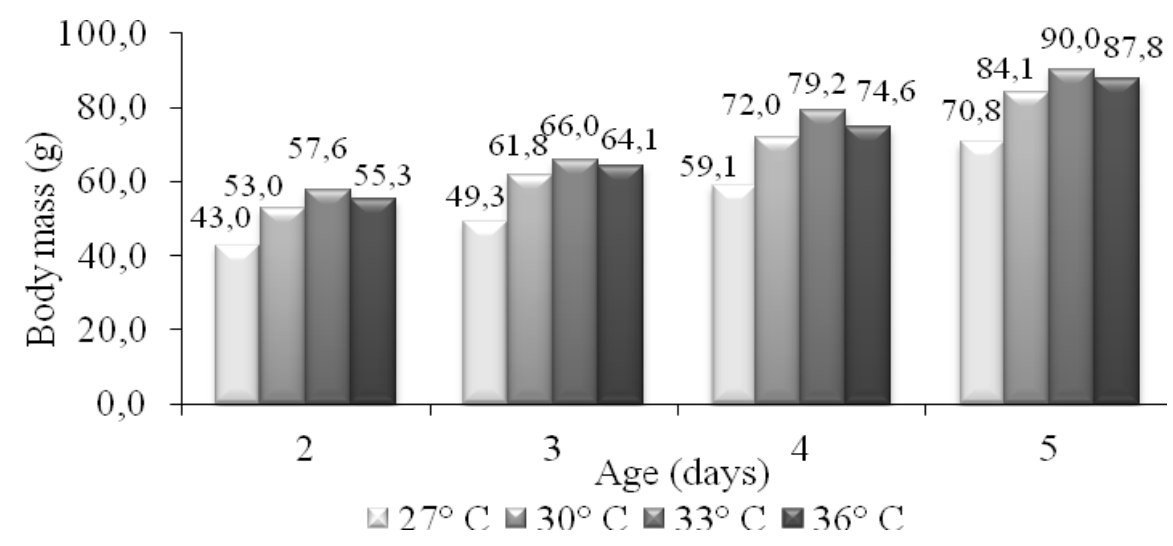

FIGURE 7. Body mass of chicks subjected to air dry-bulb temperatures of $27^{\circ}, 30^{\circ}, 33^{\circ}$ and $36^{\circ} \mathrm{C}$ during the $2^{\text {nd }}, 3^{\text {rd }}, 4^{\text {th }}$ and $5^{\text {th }}$ days of life.

\section{CONCLUSIONS}

Broiler chicks subjected to thermal challenge on the $2^{\text {nd }}, 3^{\text {rd }}, 4^{\text {th }}$ and $5^{\text {th }}$ days of life showed similar huddling or spread behaviors at lower dry-bulb air temperatures $\left(27^{\circ} \mathrm{C}\right.$ and $\left.30^{\circ} \mathrm{C}\right)$, intermediate at $33^{\circ} \mathrm{C}$, well distinct at $36^{\circ} \mathrm{C}$, following the expected classical thermoregulatory behavior.

These same birds showed similar behavior of attending the feeder or drinker when subjected to $30^{\circ} \mathrm{C}$ and $33^{\circ} \mathrm{C}$. This behavioral similarity was confirmed with measured feed intake and water intake.

However, it can be concluded that birds subjected to $27^{\circ} \mathrm{C}$ had lower feed intake, water intake and thereby less weight gain. The birds at $33^{\circ} \mathrm{C}$ showed the best performance when comparing the four evaluated dry-bulb air temperatures, $30^{\circ} \mathrm{C}$ and $36^{\circ} \mathrm{C}$ showed intermediate performance.

\section{ACKNOWLEDGMENTS}

The authors thank CAPES, CNPq and FAPEMIG for supporting this research.

\section{REFERENCES}

ABREU, P. G. de; ABREU, V. M. N.; COLDEBELLA, A.; HASSEMER, M. J.; TOMAZELLI, I. L.. Medidas morfológicas em função do peso e da idade da ave, por meio de imagens. Revista Brasileira de Engenharia Agrícola e Ambiental, Campina Grande, v. 16, n. 7, p. 795-801, jul. 2012.

ABREU, V. M. N.; ABREU, P. G. de; COLDEBELLA, A.; JAENISCH, F. R. F.; SANTOS FILHO, J. I. dos; PAIVA, D. P. de. Curtain color and lighting program in broiler production: I - general performance. Revista Brasileira de Zootecnia, Viçosa, MG, v. 40, n. 9, set. 2011.

CARGNELUTTI FILHO, A.; GUADAGNIN, J. P.. Consistência do padrão de agrupamento de cultivares de milho. Ciência Rural, Santa Maria, v. 41, n. 9, set. 2011.

CARVALHO, F.B.; SARTORI, J.R.; STRINGHINI, J. H.; FASCINA, V.B.; PEREIRA, L.A.; PELÍCIA, V.C.. Arquivo Brasileiro de Medicina Veterinária e Zootecnia, Belo Horizonte, v. 63, n. 6, p. 1437-1445, dez. 2011.

CORDEIRO, M. B.; TINOCO, I. F. F.; FILHO, R. M. de M.; SOUSA, F. C. de. Análise de imagens digitais para a avaliação do comportamento de pintainhos de corte. Engenharia Agrícola, Jaboticabal, v. 31, n. 3, jun. 2011.

DOMINICK, D.; JUAHIR, H.; LATIF, M.T.; ZAIN, S.M.; ARIS, A. Z.. Spatial assessment of air quality patterns in Malaysia using multivariate analysis. Atmospheric Environment, Oxford, v. 60, p. 172-181, dez. 2012. 
KHAN, R. U.; NAZ, S.; NIKOUSEFAT, Z.; SELVAGGI, M.; LAUDADIO, V.; TUFARELLI, V.. Effect of ascorbic acid in heat-stressed poultry. World's Poultry Science Journal, Cambridge, v. 68, n.3, p. 477 -489. set. 2012.

KHAN, R. U.; NAZ, S.; NIKOUSEFAT, Z.; TUFARELLI, V.; JAVADANI, M.; RANA, N.; LAUDADIO, V.. Effect of vitamin E in heat-stressed poultry. World's Poultry Science Journal, Cambridge, v. 67, n. 3, p. 469-478. ago. 2011.

LANA, G. R. Q.; ROSTAGNO, H. S.; ALBINO, L. F. T.; LANA, A. M. Q. Efeito da Temperatura Ambiente e da Restrição Alimentar sobre o Desempenho e a Composição da Carcaça de Frangos de Corte. Revista Brasileira de Zootecnia, Viçosa, MG, v.29, n.4, p. 1117-1123, ago. 2000.

LAU, J.; HUNG, W.T.; CHEUNG, C.S.. Interpretation of air quality in relation to monitoring station's surroundings. Atmospheric Environmetric, Oxford, v. 43, n. 4, p. 769-777. fev. 2009.

LINDEN, R. Técnicas de agrupamento. Revista de Sistema de Informação da FSMA, Macaé, v.1, n.4, p.18-36, jul./dez. 2009.

MELO JÚNIOR, J. C. F. de; SEDIYAMA, G. C.; FERREIRA, P. A.; LEAL, B. G. Determinação de regiões homogêneas quanto à distribuição de frequência de chuvas no leste do Estado de Minas Gerais.

Revista Brasileira de Engenharia Agrícola e Ambiental, Campina Grande, v.10, n.2, p.408-416, jun. 2006.

MENEGALI, I.; TINÔCO, I. de F. F.; CARVALHO, C. C. S.; SOUZA, C. F.; MARTINS, J. H.. Comportamento de variáveis climáticas em sistemas de ventilação mínima para produção de pintos de corte. Revista Brasileira de Engenharia Agrícola e Ambiental, Campina Grande, v. 17, n. 1, p. 106113, jan. 2013.

MUJAHID, A.. Acute cold-induced thermogenesis in neonatal chicks (Gallus gallus). Comparative Biochemistry and Physiology, Part A. v. 156, p. 34-41, dez. 2010.

NAZARENO, A. C.; PANDORFI, H.; GUISELINI, C.; VIGODERIS, R. B.; PEDROSA, E. M. R.. Bem-estar na produção de frango de corte em diferentes sistemas de criação. Engenharia Agrícola, Jaboticabal, v. 31, n. 1, p. 13-22, fev. 2011.

NIELSEN, B. L.. Effects of ambient temperature and early open-field response on the behaviour, feed intake and growth of fast- and slow-growing broiler strains. Animal, Cambridge, v. 6, n. 9, p. 14601468, fev. 2012.

NRC - National Research Council. Nutrient requirements of domestic animals. Nutrient Requirements of Poultry. $9^{\text {th }}$ ed. Washington, DC: National Academy Press, 1994. p. 155.

R DEVELOPMENT CORE TEAM. R: A language and environment for statistical computing. $\mathrm{R}$ Foundation for Statistical Computing, Vienna, 2012.

SAS Institute Inc. SAS/STAT 9.3 User's Guide. Cary, NC: SAS Institute, 2013. 8621 p.

SEVEGNANI, K. B.; CARO, I. W.; PADORFI, H.; SILVA, I. J. O.; MOURA, D. J. Zootecnia de precisão: análise de imagens no estudo do comportamento de frangos de corte em estresse térmico. Revista Brasileira de Engenharia Agrícola e Ambiental, Campina Grande, v. 9, n. 1, p. 115-119, jan. 2005.

SOUZA, B. B. de; BERTECHINI, A. G.; TEIXEIRA, A. S.; LIMA, J. A. de F.; CONTE, A. J.. Efeito do nível energético e da suplementação com cloretos de potássio e de amônia na dieta sobre as respostas fisiológicas e o desempenho de frangos de corte no verão. Ciência e Agrotecnologia, Lavras, v. 29, n. 1, fev. 2005.

VIGODERIS, R. B.; CORDEIRO, M. B.; TINÔCO, I. de F. F.; MENEGALI, I.; SOUZA JÚNIOR, J. P.; HOLANDA, M. C. R. Avaliação do uso de ventilação mínima em galpões avícolas e de sua influência no desempenho de aves de corte no período de inverno. Revista Brasileira de Zootecnia, Viçosa, MG, v.39, n.6, p.1381- 1386, jun. 2010. 